addition, we avoided costly and time-consuming TST of potentially exposed healthcare workers. We estimated a savings of approximately $\$ 17,000$ (administrative and supplies) for the two outbreaks through the use of immediate DNA fingerprinting. "Real time" DNA fingerprinting (where the initial positive culture from every new TB patient is sent for DNA fingerprinting) can have an almost insignificant cost compared to epidemiological investigations and erroneous treatment of patients, and may have a place in both laboratory quality assurance and in tracking or monitoring transmission.

\section{REFERENCES}

1. Tenover FC, Crawford JT, Huebner RE, Geiter LJ, Horsburgh CR Jr, Good RC. The resurgence of tuberculosis: is your laboratory ready? J Clin Microbiol 1993;31:767-770.

2. Tokars JI, Rudnick JR, Kroc K, Manangan L, Pugliese G, Hudoner RE, et al. US hospital mycobacteriology laboratories: status and comparison with state public health department laboratories. J Clin Microbiol 1996;34:680-685.

3. Jones WD. Bacteriophage typing of Mycobacterium tuberculosis cultures from incidents of suspected laboratory cross-contamination. Tubercle 1988;69:43-46.

4. Vannier AM, Tarrand JJ, Murray PR. Mycobacterial cross contamination during radiometric culturing. J Clin Microbiol 1988;26:1867-1868.

5. Small PM, McClenny NB, Singh SP, Schoolnik GK, Tompkins LS, Mickelsen PA. Molecular strain typing of Mycobacterium tuberculosis to confirm cross-contamination in the mycobacteriology laboratory and modification of procedures to minimize occurrence of false-positive cultures. J Clin Microbiol 1993;31:1677-1682.

6. Dunlap NE, Harris RH, Benjamin WH Jr, Harden JW, Hafner D. Laboratory contamination of Mycobacterium tuberculosis cultures. Am J Respir Crit Care Med 1995;152:1702-1704.

7. Wurtz R, Demarais P, Trainor W, McAuley J, Kocka F, Mosher $\mathrm{L}$, et al. Specimen contamination in mycobacteriology laboratory detected by pseudo-outbreak of multidrug-resistant tuberculosis: analysis by routine epidemiology and confirmation by molecular technique. J Clin Microbiol 1996;34:1017-1019.
8. Braden CR, Templeton GL, Stead WW, Bates JH, Cave MD, Valway SE. Retrospective detection of laboratory cross-contamination of Mycobacterium tuberculosis cultures with the use of DNA fingerprint analysis. Clin Infect Dis 1997;24:35-40.

9. Maurer JR, Desmond EP, Lesser MD, Jones WD Jr. Falsepositive cultures of Mycobacterium tuberculosis. Chest 1984;86: 439-443.

10. Smith WB, Vance DW Jr. Specimen cross-contamination by a strain of Mycobacterium tuberculosis lacking nitrate reductase activity. Diagn Microbiol Infect Dis 1991;14:523-526.

11. van Embden JDA, Cave MD, Crawford JT, Dale JW, Eisenach $\mathrm{KD}$, Gicquel B, et al. Strain identification of Mycobacterium tuberculosis by DNA fingerprinting: recommendations for a standardized methodology. J Clin Microbiol 1993;31:406-409.

12. MacGregor RR, Clark LW, Bass F. The significance of isolating low numbers of Mycobacterium tuberculosis in culture of sputum specimens. Chest 1975;68:518-523.

13. Eisenberg HD. Clinical Microbiology Procedures Handbook. Washington, DC: American Society for Microbiology; 1992:3.1.1-3.16.4

14. Bifani PJ, Plikaytis BB, Kapur V, et al. Origin and interstate spread of a New York City multidrug-resistant Mycobacterium tuberculosis clone family. JAMA 1996;275:452-457.

15. Bird BR, Denniston MM, Huebner RE, Good RC. Changing practices in mycobacteriology: a follow-up survey of state and territorial public health laboratories. J Clin Microbiol 1996;34:554-559

16. Centers for Disease Control and Prevention. Guidelines for preventing the transmission of Mycobacterium tuberculosis in health-care facilities, 1994. MMWR 1994;43(RR-13):51,69-102.

17. Centers for Disease Control and Prevention and National Institutes of Health. Agent: Mycobacterium tuberculosis, $M$. bovis. In: Biosafety in Microbiological and Biomedical Laboratories. Atlanta, GA: US Department of Health and Human Services; 1993:6-43,95,96.

18. American Society of Heating, Refrigerating, and AirConditioning Engineers. HVAC-1991 Applications. Atlanta, GA: ASHRAE; 1991;14.1-14.17.

19. American Institute of Architects, Committee on Architecture for Health. Guidelines for Construction and Equipment of Hospital and Medical Facilities, 1992-1993. Washington, DC: AIA Press; 1993:7.12, 7.31.

20. American Thoracic Society. Levels of laboratory services for mycobacterial diseases. Am Rev Respir Dis 1983;128:213.

\title{
Toll-Free Hot Line for Treating Occupational Bloodborne Pathogen Exposures
}

\section{Gina Pugliese, RN, MS Martin S. Favero, $\mathrm{PhD}$}

The US Department of Health and Human Services launched a national toll-free hot line to help clinicians counsel and treat healthcare workers with occupationally related exposures to bloodborne pathogens. The National Clinicians' PostExposure Prophylaxis Hot Line (PEPline) can be accessed from anywhere in the United States 24 hours a day. Trained physicians are prepared to provide information, counseling, and treatment recommendations for workers who have occupational exposures to bloodborne pathogens.

The hot line is a joint project of the Health Resources and Services Administration and the CDC, in collaboration with the San Francisco Department of Public Health and the University of California, San Francisco. The new hot line combines two existing programs at San Francisco General Hospital: the National HIV Telephone Consultation Service (or "Warmline"), and the University of California, San Francisco/San Francisco General
Hospital Epidemiology and Prevention Interventions Center Needlestick Hot Line.

Codirectors of the new PEPline are Ronald H. Goldschmidt, MD, and Julie L. Gerberding, MD, Epidemiology and Prevention Interventions Center director. The hot line can be accessed by calling 888-448-4911.

FROM: HHS launches national toll-free 'PEPline' for clinicians treating exposures to bloodborne pathogens. ICP Report. December 1997;171-172. Editorial. 